\title{
Going for Gold: Social Media and the USOC
}

\author{
Nicholas Gary Schlereth \\ University of New Mexico
}

\author{
Evan Frederick \\ University of Louisville
}

\begin{abstract}
The purpose of this study was to examine the social media guidelines established by the International Olympic Committee (IOC), which are enforced by the United States Olympic Committee (USOC). Specifically, this paper explored the relationship between the USOC, IOC, and the USOC athletes with regard to Rule 40 of the IOC, which regulates athlete social media use and expression of non-Olympic sponsors. This study was guided by two underlying questions: Does the social media policy from the IOC and USOC violate an American athlete's constitutional rights granted under the first amendment of the Constitution? And, when the United States Congress officially recognized the USOC in 1978, did it recognize a federally created monopoly on Olympic participation for athletes from the United States?
\end{abstract}

Keywords: USOC, IOC, athletes and social media, Rule 40, social media and policy

When an athlete qualifies for the Olympic Games, they have fulfilled a lifetime goal of competing for a gold medal. The journey is not cheap, with expenses reaching over $\$ 100,000$. These expenses are often covered by family or sponsors such as Nike and Speedo (Kindelan, 2012). If an athlete wins a gold medal, the United States Olympic Committee (USOC) will provide him or her with $\$ 25,000$. In addition, an athlete could receive a training stipend or grant, which may not be enough to cover training expenses. Athletes rely on sponsors to make their dream a reality, but while they are competing at the Olympic Games, they are forbidden from posting content on social media accounts that provide support for their sponsors (Gold Medal LLC v. USA Track and Field, 2016). The USOC must adhere to and enforce the International Olympic Committee's (IOC) policy on athletes' social media use, which prevents them from posting content related to non-Olympic sponsors during the blackout period of the Olympic Games.

The USOC was established in 1894 as the national governing body for amateur sports in the United States. Specifically, the USOC is in charge of organizing athlete development and providing training and coaching for competition in the Olympics (United States Olympic Committee, 2013). The Ted Stevens Olympic and Amateur Sport Act of 1978 provided the USOC with Congressional recognition and its

Schlereth is with the Dept. of Health, Exercise, and Sport Sciences, University of New Mexico, Albuquerque. Frederick is with the University of Louisville, KY. Address author correspondence to Nicholas Schlereth at nschlereth@unm.edu 
status as a nonprofit corporation that does not receive federal financial support but must provide a fiscal report every four years to Congress. The USOC generates its funding from corporate sponsorships, licensing, television contracts, and charitable contributions from the public. Under the Ted Stevens Act, the USOC is granted the ability to operate as a nonprofit corporation under the loose supervision of Congress. The IOC provides legislation such as Rule 40 and 50, which are tied to athlete marketing during the Olympic Games. Rule 40 focuses on Olympic athletes and their use of social media. Scholars have noted the importance of social media to an athlete's brand, as it can have an impact on fans' perceptions of their favorite athletes (Frederick, Lim, Clavio, \& Walsh, 2012). Social media has also been shown to be a tool that an athlete can use to build their personal brand (McKelvey \& Masteralexis, 2011). While the USOC provides marketing assistance for its athletes, Olympic athletes often have a limited window to capitalize on their notoriety and fame. Therefore, Olympic athletes must take advantage of the opportunity afforded to them and build relationships with fans through social media and leverage social media for their benefit with regard to endorsements.

The USOC and IOC encourage athletes to partake in social media; however, they are protective of their property to ensure that ambush marketing does not occur during the Olympic Games (International Olympic Committee, 2015a). In Rule 50 , the IOC explicitly states that ambush marketing will not be tolerated. This only applies to Olympic venues and facilities, not to social media. Social media usage by athletes is encouraged by the IOC so that athletes can share their experiences with family and friends (International Olympic Committee, 2016). With that said, Rule 40 places limitations on athletes regarding content that can be posted via social media in relation to athletes' sponsors. The purpose of this paper is to examine the social media guidelines established by the IOC, specifically Rule 40, which is enforced by the USOC. The examination will focus on two primary areas: the legality of this policy under the Constitution of the United States and the cartel-like behavior exhibited by the USOC in their management of athletes. This study is guided by two underlying questions: Does the social media policy from the IOC and USOC (i.e., Rule 40) violate an American athlete's constitutional rights granted under the first amendment of the Constitution? And, when the United States Congress officially recognized the USOC in 1978, did it recognize a federally created monopoly on Olympic participation for athletes from the United States?

This paper is intended to be a commentary on the social media policy instituted by a state actor on nonemployees and its potential infringement on athletes' rights. The goal of the present study is to explore the relationship between the USOC, IOC, and the USOC athletes in relation to Rule 40 of the IOC, which regulates athletes' social media use and expression of non-Olympic sponsors. This commentary will first examine the business model of the USOC, followed by an understanding of Rule 40 and USOC policy adaptations. After the foundation of the USOC's business model and Rule 40 policies are presented, there will be a discussion regarding whether the actions of the USOC constitute a violation of anti-trust law. In other words, by adhering to IOC policies, is the USOC violating an American athlete's constitutional rights by suppressing their freedom of speech on social media platforms? The intention of this commentary is to enhance and encourage discussion surrounding athletes' rights to self-promotion and the ability to maximize their likeness. 


\section{Business Model of United States Olympic Committee}

The USOC is a federally recognized nonprofit corporation that does not receive funding from the federal government but must rely on broadcast and media rights, licensing fees, and charitable contributions (United States Olympic Committee, 2013). According to the Ted Stevens Olympic and Amateur Sports Act, Congress established the purpose of the USOC in 14 areas, including establishing national goals for amateur athletic activities, encouraging attainment of these goals, coordinating and developing amateur athletic activity in the United States, and encouraging the development of activities for female athletes. The act provided a definition for amateur athlete as "an athlete who meets the eligibility standards established by the national governing body or Paralympic sports organization for the sport in which the athlete competes" (Ted Stevens Olympic and Amateur Sports Act, 1978, p. 91). The act did a great deal to provide legitimacy for the USOC, but it does not provide the USOC with any funding. In that regard, the USOC has a striking resemblance to the National Collegiate Athletic Association (NCAA) in its organizational structure and financial strategy.

The USOC's main source of revenue is media rights. According to their audited financial statement for the 2015 fiscal year, the USOC received $\$ 585,000$. The amount is fairly small when you examine the 2014-2020 television contract with NBC/Comcast Corporation, which will total \$558,578,000 (GrantThornton, 2016). The contract stipulated that an allotment of funds for future games would be held in a trust that was able to accrue interest on top of the stated amount provided by the NBC/Comcast Corporation. The expected payment for 2016, including the Olympic Games, will bring an increase of over \$1.5 million on top of the expected $\$ 6.5$ million in media rights compensation. The second-largest form of revenue for the USOC is the collection of royalties for the use of the USOC's mark and licensing royalty income, which brought in a total of $\$ 102,254,000$ or $\$ 98,309,000$ and $\$ 3,945,000$, respectively (GrantThornton, 2016). The USOC also receives a great deal of donations from individuals and corporations, which are a tax write-off for the individual or corporation due to the USOC's status as a nonprofit organization. Revenues are not an area of weakness for the USOC, partly because they do not compensate their athletes directly, nor do they have an established relationship with their athletes as seen with other professional sports organizations in the United States (United States Olympic Committee, 2015a). Compensation is given to athletes through a training grant, which is not given to each athlete. The second form of athlete compensation comes from winning a medal.

\section{The USOC-Athlete Relationship}

The USOC does not treat its athletes as employees. Compensation to athletes comes in the form of a training grant, but it is not distributed to every athlete. According to audited financial statements, USOC distributed $\$ 76,500$ total in grants, which includes national governing body and adaptive sport organization grants, athlete grants, elite athlete health insurance and other medical benefits for athletes, Olympic and Paralympic Games bid support, and International assistance (GrantThornton, 2016). A total of $\$ 16,987$ was spent on athlete grants, accounting for $22 \%$ of the 
overall expense on grants. Based on the size of the USOC 2016 Olympic delegation of 554 athletes, if the $\$ 16,987$ was distributed evenly to every athlete, each athlete would receive $\$ 30.66$, which is hardly enough to provide a living wage or support training costs. The athletes are not considered employees of the USOC or their individual federations; as such, they experience a similar relationship in terms of employment as do student-athletes in the NCAA.

The USOC is a nonprofit organization that has been provided a charter to operate by Congress. Under the charter, the USOC operates like any other nonprofit organization through fundraising and donations, but it has the additional luxury of receiving licensing fees for their marks and receiving a share of television revenues to broadcast USOC and Olympic events. The USOC is placed in a precarious position as their charter pertains to rights granted to their athletes from the United States government. However, it must adhere to policies established by the IOC or face scrutiny and the possibility of funding being withheld for not complying with the IOC's policies.

\section{A Complicated Relationship: USOC and IOC}

The USOC is primarily responsible for executing sport in the United States and leading the development of sport through the sponsoring of various sport federations. The IOC is the governing body for the Olympics and actively works to protect the Olympic brands and their sponsors. In order to maximize sponsor revenue, the IOC began giving exclusive rights to sponsors (Masteralexis, Barr, \& Hums, 2015). The IOC attempts to protect the exclusive nature of these sponsorships through the use of Rule 40 and Rule 50. These rules have a substantial impact on the athletes competing at the Olympics. Rule 50 is an action from the IOC to limit the exposure of outside brands in and around Olympic venues. It could be called the squeakyclean rule because it limits signage and visuals, as well as logo placement on athlete equipment (International Olympic Committee, 2016). The policies instituted by the IOC are intended to protect the IOC's corporate sponsors, thereby limiting the ability of athletes to maximize their financial potential from the exposure gained through the platform provided by the Olympic Games.

\section{Rule 40}

Rule 40 has quickly become a contested policy among IOC stakeholders, ranging from apparel manufactures to athletes who are not pleased with the limitations the rule places on them. Rule 40 of the Olympic Charter states: "Except as permitted by the IOC Executive Board, no competitor, coach, trainer or official who participates in the Olympic Games may allow his person, name, picture or sports performances to be used for advertising purposes during the Olympic Games" (International Olympic Committee, 2015b, p. 79). The policy is directed at the athletes and, more importantly, at their sponsors because it prevents sponsors from using an athlete's likeness in a promotional manner during the Games. In a 2015 memo to national governing organizations and their athletes, the IOC provided guidance on terms that could be used in commercial messaging, including "Olympic, Olympics, Olympic Games, Olympiad, Olympiads, The Olympic motto, 2016, Rio/Rio de Janeiro, Gold, Silver, Bronze, Medal, Effort, Performance, Challenge, Summer, Games, 
Sponsors, Victory, and Olympian" (International Olympic Committee, 2015a, p. 3 ). Non-IOC sponsors must get creative to leverage the exposure of their athletes in the Games, or else they are missing out on a large marketing opportunity, one described by Phil Knight as being crucial to a brand (Knight, 2016).

Under pressure from stakeholders, the IOC announced a relaxation of the blackout period surrounding the 2016 Rio Olympics (Roberts, 2016). The move by the IOC allowed non-IOC sponsors to use their sponsored athletes in advertising during the Olympic Games, but they still could not use official Olympic slogans that are forbidden in Rule 40. Roberts (2016) explained that athletes could tweet or share information about their non-IOC sponsors as long as they followed the same rules as the brands. An example would be Michael Phelps tweeting "Working hard in the pool tonight-thanks, Under Armour," which is permitted. An unpermitted tweet would be "Training real hard for Rio. Thanks, Under Armour." While the IOC adapted its policy, it still provides restrictions on athletes' rights to free speech and their ability to fully capitalize on earning potential as the athletes cannot fully align their brand with one of the most watched international sporting events (Shank \& Lyberger, 2014).

While it is true that athletes will be recognized from exposure in the Olympics, if they cannot fully link to the Olympics, their content will be no different than something they could post outside of the Olympic blackout dates. The Olympics provide a stage for athletes, and their ability for free speech is impeded by the IOC through Rule 40 and the USOC's enforcement of this policy. An Olympic athlete is not an employee of the USOC or IOC (United States Olympic Committee, 2016). However, these associations tend to treat athletes like employees through their regulatory functions. Other professional sports leagues such as the National Football League (NFL) have developed a social media policy for their players, who are employees of the NFL and its subsidiary franchises. The NFL shifted the power of developing social media policies to its individual franchises, but the NFL noted that the content posted should be "professional, accurate, and consistent with the NFL and club's mission values" (National Football League, 2016, pp. 17-18). The NFL does not prevent players from posting content that is tied to their personal sponsors during the NFL season, which has not hindered the league's ability to generate over $\$ 13$ billion annually from a similar business model employed by the IOC (Belzer, 2016).

While Rule 40 is controversial, most of this heightened attention has been fueled by corporate sponsors that want to capitalize on their athlete endorsers competing on the Olympic stage. It is important to focus on the rights infringement that is occurring in terms of limiting an athlete's ability to capitalize on their likeness and the paternalistic actions of the IOC, which effectively tells athletes what they can post on their social media accounts during the Olympics. This infringement is the predominant focus of our discussion, especially for American athletes, who are protected by the U.S. Constitution and given the right to freedom of speech.

\section{Rule 40 and Freedom of Speech}

The Supreme Court, in its 2015 decision on Elonis v. US, issued protection for freedom of speech on social media. The United States is governed by its Constitution, which grants its citizens basic rights, with freedom of speech being one of 
the most protected but often one of the most questioned rights in sport (Epstein, 2012; Gay, 2011; Sanderson, Snyder, Hull, \& Gramlich, 2015; Snyder, Hutchens, Jones, \& Sun, 2015). Snyder et al. (2015) discussed the passage of laws in 12 states to limit student-athletes' usage of social media and the ability for a university to provide oversight and limit student-athletes' use of various platforms. They found that the laws were not treating the student-athletes fairly, because those laws limited student-athletes' ability to use social media, with limitations often emanating from a state actor (i.e., a federal, state, city, or municipal entity often receiving federal funding). Since the USOC are recognized by Congress, which outlined their function and purpose, one could reasonably argue through the use of public function theory or nexus entanglement theory (see Cotten \& Wolohan, 2013) that the USOC is indeed a state actor. If the USOC is found to be a state actor (though this has never happened), it would not be able to act in a manner that suppresses the free speech of athletes because of its standing as a governmental agency.

Scholars have not attempted to scrutinize the USOC for their social media policies. Existing research has primarily focused on the NCAA, social media policy, and student-athletes. This limited body of research has revealed that social media policies often focus on content restrictions (Sanderson, 2011) and that social media education is often laden with forgettable messages (Sanderson, Browning, \& Schmittel, 2015). In addition, researchers have noted that student-athletes are often presented with conflicting messages regarding ownership of social media content (Sanderson, Snyder, et al., 2015). The latter point seems to align quite well with the current state of the USOC and the athletes under its purview.

Conceptually, the NCAA and USOC operate a similar business model with regard to issuing grants to athletes for competing and training in their sport. The organizations and their policies are different because the NCAA is able to derive policy for its member institutions, whereas the USOC must adhere to policies that are passed down from the IOC. Pertaining to social media, the NCAA does not have to worry about athletes posting content from sponsors because this would violate the athletes' amateurism, but the question of freedom of speech through social media is applicable to both organizations. Since the literature is sparse when addressing social media policy pertaining to Olympic athletes and the USOC, relying on the literature from the NCAA is permissible. A primary contribution of this study to the literature is its commentary pertaining to IOC and USOC social media policies and its impact on athletes' rights.

\section{Olympic Athlete Rights and Social Media}

Scholars contend that social media platforms allow for greater control of content by laypeople (Sanderson, 2011), providing them with a platform to put their voice on display (Clavio, 2013). Furthermore, these platforms allow users to bypass traditional media (Sanderson, 2010) and provide immediacy of information (Sanderson and Hambrick, 2012). In addition, social media afford athletes with an opportunity not only to control their own identity but also to impact brand equity and brand personality (Burch et al., 2014). With that said, it is the stance of the authors of the present study that, with regard to social media and its ability to positively impact an athlete's brand and endorsement dollars, an Olympic athlete from the United States should not have to forgo the right to freedom of speech to participate in the 
Olympic Games. The IOC encourages athletes to use social media to promote the Olympics, but the IOC is hypocritical in seeking free promotion of its product without providing compensation to the athletes for their promotional activities. The IOC encouraging athletes to post content promoting the Olympics and their Olympic experience is acceptable. The act of limiting an athletes' ability to capitalize on their own likeness in conjunction with the Olympics could be an anti-trust violation by the USOC during the Olympic blackout dates. The USOC, in executing the policies of an international organization on its athletes, should be cognizant of the ways the policies infringe on the rights of its athletes. The United States should not be held captive by the IOC through policy that limits U.S. athletes' rights.

The IOC has every right to develop and implement policy to protect the Olympics and their sponsors, but when the policies interfere with rights granted by a country to its citizens, then that country should resist the change or offer an alternative for the athletes. The USOC has provided an alternative for its athletes in the waiver system, which allows athletes to list sponsors and seek approval for their sponsors. A critical caveat of the waiver system requires athletes to submit their waiver request six months in advance of the Olympic Games. The purpose of the waiver system is to accomplish three primary goals: enable continuation of in-market generic advertising featuring the Rio Games participants during the Games period, protect exclusive Olympic/Paralympic sponsor rights to use Olympic/Paralympic intellectual property, and ensure that all stakeholders understand that each National Olympic Committee/National Paralympic Committee will be responsible for Games participant advertising guidance and enforcement within its own territory (United States Olympic Committee, 2015b, p. 3). While the waiver system is a move in the right direction, it is still a limitation emanating from policies that are ultimately an infringement on athletes' rights.

The guidance offered by the USOC is a clear indicator of its position as the enforcement agency for the IOC's policies. A question should be raised to the athletes under the purview of the USOC regarding which master they should serve, an international body or Congress. The policies of the IOC should not have greater significance than the rights and liberties protected in the United States Constitution. The next question focuses on the standing of the USOC as the primary vehicle for an individual to realize his or her Olympic dreams.

\section{The USOC and Anti-Trust Concerns}

The USOC faced one anti-trust lawsuit in 2016 from distance runner Nick Symmonds. Symmonds' company Gold Medal LLC brought a suit against the United States Track and Field Federation and the USOC, claiming an illegal restraint of trade under section one of the Sherman Act. The restriction of trade surfaced out of policy forbidding athletes from competing at the Olympics in apparel bearing individual sponsorships. The lawsuit was dismissed by the District Court of Oregon because of an implied grant of immunity given to the USOC by the Ted Stevens Olympic and Amateur Sports Act (Gold Medal LLC v. USA Track and Field \& USOC, 2016).

The decision from the District Court in Oregon provided a sizable blow to the argument that the USOC acts in a manner that prevents athletes from seeking alternative options for promotional opportunities on the international stage. If an 
athlete were to bring a suit against the USOC for limitations placed on him or her by Rule 40, the courts would most likely side with the USOC because of USOC's implied immunity from Congress. It does not mean that a suit could not be brought against the USOC challenging the legitimacy of the "implied immunity" claim supported in the District Court, but one would have to prove a compelling case to show damages caused by the USOC's monopoly of international sport competition.

Symmonds has voiced his displeasure with the USOC, asserting that it should allow him to publicize his sponsors during competitions in which he is representing the United States. It is understandable why the USOC would prohibit Symmonds from wearing non-USOC sponsors in competition; one could argue that he would be utilizing the stage provided to him by the USOC for his personal gain. Symmonds has been known to wear sponsored logos during professional competition in the form of stickers placed on his skin. One of the primary focus areas of his case against the USOC and USA Track and Field was the ability of an organization to dictate Symmonds' actions in exchange for competing for the United States. It is a perplexing position for Symmonds because he is not an employee of the USOC or USA Track and Field, but he needs these organizations to compete for his country in international and Olympic competitions.

Since Symmonds is not an employee of either organization and does not receive compensation in the scope of employment, he could have a valid argument. If he were a football player in the NFL, he could be told what to wear and could be punished in the form of a fine. It is within the scope of the NFL's employment contract to levy a fine because the players are employees of the NFL and are obligated to comply with the dress code. In this particular instance, Symmonds wanted to wear the logo of his personal company during international competition, where he was representing the United States. Symmonds is not an employee of the USOC or USA Track and Field; therefore, he did not deserve the threats of punishment for not complying with the policy. A similar case occurred in the NFL with Marshawn Lynch wearing his own logoed apparel "Beast Mode" during media interviews, resulting in a fine for Lynch. The "implied immunity" granted to the USOC in the Symmonds case was attributed to the Ted Stevens Act, which effectively provided the USOC with protection from anti-trust cases, thus granting the USOC a legal monopoly in giving Olympic access to American athletes. A 1998 revision of the Ted Stevens Act provided immunity for the USOC, stating: "[A]t the request of the USOC, a case could be dismissed in a district court" (36 U.S.C. $§ 220505$ ). The decision in the Symmonds case provides greater clarity on the legal environment surrounding anti-trust cases against the USOC, specifically in the area of social media. Symmonds' case could have a ripple effect for other athletes, particularly in the realm of Olympic athlete use of social media. The revision to the Ted Stevens Act, which enabled the court to make the decision in the Symmonds case, allowed the USOC to establish itself more firmly as a state actor and reinforce its authority over U.S. Olympic athletes.

\section{Conclusion}

The USOC is an organization that possesses substantial power over its athletes, who are placed in a perplexing position because they must obey the USOC and IOC, or else they will be fined or prevented from competing in the Olympics. The purpose of this commentary was to introduce concerns surrounding the USOC and 
IOC instituting a rule to deter athletes from capitalizing on their likeness during the duration of the Olympic Games-more specifically, by preventing athletes from posting social media content and material tied to their sponsors that are often not official sponsors of the Olympics. At the onset of the commentary, we proposed two questions that guided our discussion. The first question was, does the social media policy from the IOC and USOC violate an American athlete's constitutional rights granted under the first amendment of the Constitution? We believe the policy does infringe on the athlete's first amendment rights because it limits athlete's ability to express themselves in a manner that can enhance their economic standing. Since the USOC was recognized and granted power to oversee Olympic sport in the United States, it is a legitimate state actor and should not have the ability to suppress an American citizen's right to freedom of speech (Ted Stevens Olympic and Amateur Sports Act, 1978). While the Ted Stevens Act does not mention freedom of speech in its language, it should be a foregone conclusion that a state actor, serving as a state recognized facilitator of sport, should not be able to infringe upon United States citizens' rights granted in the Constitution. A 2016 decision from the U.S. District Court of Oregon recognized the USOC as a state actor when that court enforced immunity from anti-trust laws granted by Congress.

The second question that guided this discussion was, did Congress recognize a federally created monopoly of Olympic participation for athletes from the United States with the Ted Stevens Act? After reviewing the Ted Stevens Act, it is evident that Congress had the intention of creating a body that would regulate and facilitate Olympic sports in the United States, but it did not fully recognize them as a monopoly. A monopoly can be granted by the government on limited status if it is in the best interest of the public. Hawley (2015) discussed monopolies as vital in public entities such as natural resources and communication; he also noted that distributive trades "could be torn apart if they are labeled as monopolies" (p. 482). As discussed earlier, the USOC was given the power to advise the district court to dismiss any civil action brought against it. This appears to only enhance the argument that the USOC is indeed a monopoly controlling Olympic sport in the United States. The USOC is indeed a state actor because it was granted the ability to function in the current manner by the United States Congress. While it does not directly answer to any governmental agency, it is required to deliver a report to Congress every four years. Congress does serve as the default oversight body to the USOC. Did Congress create a monopoly when they officially recognized the USOC? We believe the answer is yes.

In order for a monopoly created by Congress to be legitimized as a limited governmental monopoly, or "de jure monopoly," similar to the United States Postal Service, it must be in the best interest of the public (Crew \& Rowley, 1988; Hawley, 2015). When Congress recognized the USOC in 1978, the United States was facing the introduction of many new social programs, including Title IX. Perhaps Congress presumed that recognizing the USOC as the primary vehicle for Olympic sport oversight would ensure that Title IX would be implemented in a fair manner in sport. In the Ted Stevens Act, Congress instructed the USOC to ensure the development of sport and provide the opportunity for increased access. While one cannot claim to know the thought process of the United States Congress, it does appear that the decision to recognize the USOC was a step to ensure that Title IX would be implemented in the realm of Olympic sport. 
It appears Congress had the intention of providing the full support of the federal government to the USOC, based particularly on its recognition of the USOC in the Ted Stevens Act. The decision of the District Court of Oregon to uphold the status of the USOC further clarified the USOC's exempt status as a monopoly, thereby providing additional recognition by the people and federal courts of the power and prominence of the USOC. Due to the prominence and revenue generation of the USOC, it could be questioned if the USOC should have greater oversight than having to submit a quadrangle report to Congress; we feel the USOC should be subject to an oversight committee. This oversight is necessary, as the USOC is a large and powerful organization with great control over the United States' participation in the Olympic Games.

\section{Where Do We Go From Here?}

The Olympics are one of the largest sporting events in the world, which means a great deal of admiration and scrutiny will be found in its wake. We focused primarily on the USOC and its role in enforcing a policy established by an international body over United States citizens who participate in the Olympic Games. Since the USOC was found to be immune from anti-trust law, having the ability to function as the lone authoritative body over U.S. Olympic athletes' conduct and behavior, it can continue to enforce its strict regulations regarding athletes' use of social media in posting non-IOC sponsors during the Olympic Games. The ground swell of support for the athletes' ability to leverage social media platforms to capitalize on their likeness garnered more attention during the 2016 Rio Olympic games, which led to further turmoil between athletes and their personal sponsors (Birkner, 2016; Roberts, 2016).

Social media is a rapidly changing form of communication. The utilization of these platforms have led to an increased awareness and generated dialogue around events such as the Olympics. Social media allows fans and other stakeholders to engage with athletes in a manner that was previously only attainable through exclusive access provided by the athletes' team or organization (Lebel \& Danylchuk, 2014). The Sochi Winter Olympics was one of the first times that fans got to see behind the Olympic curtain as they were exposed to social issues in Sochi, especially the issue of stray dogs in the streets (Beech, 2015) as well as issues related to LGBT rights and conditions and accommodations in Sochi (Frederick, Pegoraro, \& Burch, 2016). Social media provides an opportunity to enhance the fan experience, due to heightened interactions with athletes (Lebel \& Danylchuk, 2014). In addition, social media outlets are vital to an athlete who is attempting to maximize his or her identity and support his or her sponsors during times of high visibility. The Olympic Games provide a platform for athletes to be exposed to millions, if not billions, of people around the world. The imposed limit placed on the athlete by the IOC and enforced by the USOC hinders an athlete's earning potential and impedes on his or her right to freedom of speech. The relationship between the USOC and IOC needs to be reevaluated as it is hindering the athletes' ability to capitalize on their notoriety while competing in the games and limiting their rights. Social media has the potential to maximize the connection between fans and stakeholders and generate greater value, enhancing future earning potential for all parties 
involved with the Olympics. Therefore, a careful reevaluation of the policies governing its use is in order.

Olympic athletes have a couple of options. First, they could stick with the status quo. Second, they could collectively organize into a union. Organizing into a union would provide these athletes with the ability to demand a greater share of the overall revenue that would not have existed without them competing for the United States and the USOC. Unionization and increased litigation was sought by college athletes against the NCAA. The strategy by former and current NCAA athletes was to chip away at the NCAA on various fronts, starting with the use of one's likeness in the O'Bannon case. More recent cases have focused on medical and employment concerns including Kessler, Alston, and other cases surrounding concussions (Berkowitz, 2016). The option of unionization provides potential for the athletes, based on the precedent set by the National Labor Relations Board (NLRB) and state labor relations boards.

Collectively organizing into a union could provide athletes with greater leverage in dealing not only with USOC but also with the individual federations that control their respective sports. The NLRB's decision in the Northwestern University football players' attempt to unionize did not address whether players could unionize, because they were not employees; instead, the decision focused on the jurisdiction of the NLRB over public institutions (National Labor Relations Board, 2015). In a 2016 decision relating to volunteer firefighters seeking unionization, the Pennsylvania Labor Relations Board granted union status for volunteer firefighters, because they served a similar role as paid firefighters and received some form of compensation (Chambersburg Borough v. Pa. Labor Relations Board). The findings from the Northwestern and volunteer firefighters' cases could provide precedent for establishing a union as nonemployees.

The primary focus of this commentary was on the athletes' ability to leverage social media platforms to capitalize on their likeness during the Olympic Games. The IOC has passed implementation and enforcement of their policies on to individual organizing committees. Therefore, the athletes could work with the USOC to negotiate the use of restricted words-such as gold, silver, and bronze-within their personal sponsor promotions via social media. While we cannot speak for future actions or rulings of a court, the limitations placed on Olympic athletes from the United States in terms of not being allowed to use generic words in their promotional social media content could be found to be overly restrictive.

Further research should be conducted to examine the impact of an athlete's posts when they discuss their personal sponsor(s). The IOC's primary concern and reason for enacting Rule 40 is based on the fear of ambush marketing. It does not want its platform being leveraged for the personal gain of others, because its revenues originate predominantly from marketing efforts (International Olympic Committee, 2016). An empirical examination of an athlete's impact and reach would be beneficial to provide a foundation for an athlete's claim that his or her personal sponsor can be advertised simultaneously with the IOC sponsors in the same manner as with the NFL and other professional leagues in the United States (Belzer, 2016). The athletes must be the driving force behind changes in the USOC and IOC. If they do not lead this change, then the party with the power will continue to impose its will on a divided workforce. 


\section{References}

Beech, M. (2015, July 9). Stray dogs of Sochi are bringing Olympic joy to their new owners. Retrieved August 8, 2016, from http://www.si.com/more-sports/2015/07/09/sochidogs-2014-winter-olympics

Belzer, J. (2016, February 29). Thanks to Roger Goodell, NFL revenues projected to surpass $\$ 13$ billion in 2016. Retrieved August 6, 2016, from http://www.forbes.com/sites/ jasonbelzer/2016/02/29/thanks-to-roger-goodell-nfl-revenues-projected-to-surpass13-billion-in-2016/

Berkowitz, S. (2016, August 5). Judge rejects NCAA's request for dismissal of "Kessler," Alston suits. Retrieved November 16, 2016, from http://www.usatoday.com/story/sports/ college/other/2016/08/05/ncaa-suit-shawne-alston-martin-jenkins-kessler-bermannigel-hayes-claudia-wilken/88313408/

Birkner, C. (2016, July 5). How the Olympics' new advertising rules will impact athletes and brands in Rio. Retrieved August 16, 2016, from http://www.adweek.com/news/ advertising-branding/how-olympics-new-advertising-rules-will-impact-athletes-andbrands-rio- 172372

Burch, L.M., Clavio, G., Eagleman, A.N., Major, L.H., Pedersen, P., Frederick, E.L., \& Blaszka, M. (2014). Battle of the sexes: Gender analysis of professional athlete tweets. Global Sport Business Journal, 2(2), 1-21.

Chambersburg Borough v. Pa. Labor Relations Board (Pa. Labor Relations Board 2016).

Clavio, G. (2013). Emerging social media and applications in sport. In P.M. Pedersen (Ed.), Routledge handbook of sport communication (1st ed., pp. 259-268). New York: Routledge.

Cotten, D., \& Wolohan, J.T. (2013). Law for recreation and sport managers (6th ed.). Dubuque, IA: Kendall Hunt.

Crew, M.A., \& Rowley, C.K. (1988). Toward a public choice theory of monopoly regulation. Public Choice, 57(1), 49-67.

Epstein, T.L. (2012). Regulation of student athletes' social media use: A guide to avoiding NCAA sanctions and related litigation. Mississippi Law Journal. Retrieved from http:// papers.ssrn.com/sol3/papers.cfm?abstract_id=1998315

Frederick, E.L., Lim, C.H., Clavio, G., \& Walsh, P. (2012). Why we follow: An examination of parasocial interaction and fan motivations for following athlete archetypes on Twitter. International Journal of Sport Communication, 5(4), 481-502. doi:10.1123/ijsc.5.4.481

Frederick, E.L., Pegoraro, A., \& Burch, L.M. (2016). Echo or organic: Framing the 2014 Sochi Games. Online Information Review, 40(6), 798-813. doi:10.1108/OIR-02-20160038

Gay, J. (2011). Hands off Twitter: Are NCAA student-athlete social media bans unconstitutional? Florida State University Law Review, 39, 781-805.

GrantThornton. (2016). United States Olympic Committee audited financial statement (pp. 34). Denver: United States Olympic Committee.

Gold Medal LLC v. USA Track \& Field, Civ. No. 6: 16-cv-00092-MC (D. Or. May 11, 2016).

Hawley, E.W. (2015). The New Deal and the problem of monopoly. Princeton, NJ: Princeton University Press.

International Olympic Committee. (2015a). 2016 Olympic Games-Rule 40 guidelines. Rio: International Olympic Committee.

International Olympic Committee. (2015b). Olympic Charter. International Olympic Committee.

International Olympic Committee. (2016a). IOC marketing: Media guide (pp. 64). Switzerland: International Olympic Committee.

International Olympic Committee. (2016b). Rule 50 of the Olympic Charter: What you need to know as a participant. International Olympic Committee. 
Kindelan, K. (2012, August 6). Olympians' parents pay the cost for achieving gold. Retrieved from http://abcnews.go.com/US/olympics/olympians-parents-feel-debt-achieving-gold/ story? id $=16940902$

Knight, P. (2016). Shoe dog: A memoir by the creator of Nike. New York: Scribner.

Lebel, K., \& Danylchuk, K. (2014). An audience interpretation of professional athlete self-presentation on Twitter. Journal of Applied Sport Management, 6(2). Retrieved from http://search.proquest.com/openview/ab0fc7a067dc6f932e 7148515145fc37/1 ?pq-origsite $=$ gscholar

Masteralexis, L., Barr, C., \& Hums, M. (2015). Principles and practice of sport management (5th ed.). Burlington, MA: Jones \& Bartlett Publishers.

McKelvey, S., \& Masteralexis, J.T. (2011). This tweet sponsored by . . . : The application of the new FTC guides to the social media world of professional athletes. Virginia Sports and Entertainment Law Journal, 11, 222-246.

National Football League. (2016). Compliance plan (pp. 20). New York: National Football League.

National Labor Relations Board. (2015). Northwestern University decision. Washington, DC: National Labor Relations Board.

Roberts, D. (2016, August 3). Why the biggest business story of the Rio Olympics is this marketing rule change. Retrieved August 5, 2016, from http://finance.yahoo.com/news/ rio-olympics-rule-40-changes-marketing-summer-games-200732935.html

Sanderson, J. (2010). Framing Tiger's troubles: Comparing traditional and social media. International Journal of Sport Communication, 3(4), 438-453. doi:10.1123/ijsc.3.4.438

Sanderson, J. (2011). To Tweet or not to Tweet: Exploring division I athletic departments' social media policies. International Journal of Sport Communication, 4, 492-512. doi:10.1123/ijsc.4.4.492

Sanderson, J., Browning, B., \& Schmittel, A. (2015). Education on the digital terrain: A case study exploring college athletes' perceptions of social-media training. International Journal of Sport Communication, 8, 103-124. doi:10.1123/IJSC.2014-0063

Sanderson, J., \& Hambrick, M.E. (2012). Covering the scandal in 140 characters: A case study of Twitter's role in coverage of the Penn State saga. International Journal of Sport Communication, 5(3), 384-402. doi:10.1123/ijsc.5.3.384

Sanderson, J., Snyder, E., Hull, D., \& Gramlich, K. (2015). Social media policies within NCAA member institutions: Evolving technology and its impact on policy. Journal of Issues in Intercollegiate Athletics, 8, 50-73.

Shank, M.D., \& Lyberger, M.R. (2014). Sports marketing: A strategic perspective. New York: Routledge.

Snyder, E.M., Hutchens, N.H., Jones, W.A., \& Sun, J.C. (2015). Social media policies in intercollegiate athletics: The speech and privacy rights of student-athletes. Journal for the Study of Sports and Athletes in Education, 9(1), 50-74. doi:10.1179/1935739 715Z.00000000035

Ted Stevens Olympic and Amateur Sports Act, 2205 91-113 (1978).

United States Olympic Committee. (2013). United States Olympic Committee: 2012 quadrennial report (pp. 393). United States Olympic Committee.

United States Olympic Committee. (2015a). United States Olympic Committee: Report of organization exempt from income tax (Tax Form No. Form 990) (pp. 52). United States Olympic Committee.

United States Olympic Committee. (2015b). USOC athlete advertising waiver system. United States Olympic Committee.

United States Olympic Committee. (2016). Bylaws of the United States Olympic Committee. United States Olympic Committee. 